\title{
Validity of Android Based Mobile Learning Media in Computer and Based Network Vocational High School
}

\section{Reska Mayefis ${ }^{1 *}$, Sukardi², Usmeldi ${ }^{3}$}

1,23 Universitas Negeri Padang, Padang, Indonesia

A R T I C L E I N F O

Article history:

Received 15 August

2019

Received in revised

Form 29 September

2019

Accepted 18 October

2019

Available online 29

November 2019

Keywords:

Android, Media, Mobile

learning, Validity

\section{A B S T R A C T}

The purpose of this research is to produce a valid android based mobile learning media that is suitable for learning in Computer and Based Network subjects. This android based mobile learning media is designed to increase student interest in learning, to improve student understanding about learning material and also to improve learning outcomes. This is a Research and Development (R\&D) with 4-D model (Define, Design, Develop, Disseminate). In this study is limited to the development stage, is to know the validity of the mobile learning media from material and media experts. Data analysis techniques is descriptive analysis techniques to describe the validity of the android based mobile learning media. Media validity is measured through a validated instruments that has been previously validated. The validity results from this research are android based mobile learning media declared valid in terms of media aspects and material aspects. Based on the results of this validity, it is concluded that the android based mobile learning media was declared valid for use as Computer and Based Network learning media. 


\section{Introduction}

The use of mobile devices for education especially computing education is constantly gaining interest rapidly among researchers and educators (Ihantola et al. 2013; Tortorella and Graf 2017; Hürst et al. 2007; Mahmoud and Dyer 2008; Jordine et al. 2015; Moreira and Ferreira 2016; Mbogo et al. 2013; Oyelere et al. 2016a; Prenner et al. 2014). Recently new technology whose most of the people have been commonly using is smartphones which has been developed massively for many purposes. The purposes on this research is the connection between academic learning and smartphone if we used effectively it can be a tool of learning. The effect of using smartphones on learning process can be either positive or negative. Although there are still some students who still do not use smartphones as a tool in learning. The method used by students in using smartphones for learning is different for each individual, the teacher as an educator only needs to find the best and most useful way for the smartphone to be effectively used in learning. In order to find out whether smartphones are used to have effectiveness benefits for learning, we can measure them through the value students get at the end of learning, although this method cannot be too accurate to measure students' abilities and effectiveness of using smartphones for learning.

Based on observations at vocational high schools 2 in Padang, Indonesia, in the form of student's needs assessment instruments, students do use smartphone most of their time. Most of their times, the students use smartphone only for informal learning for example to search for information like access course material. This can prove what Chen \& Denoyelles, (2013) have said; rather than formal academic, students usually only use their mobile technology more for informal learning. Even though they think smartphones can be a good tool for education, their main purpose of using smartphone is to access social media rather than for learning tools, more than half of respondent admit this. The most frequent category of apps used is social media, followed by games $25 \%$. Books in the smartphone only $15 \%$ of the students access it and listening to music are end up with $9 \%$. This discovery verifies what Alfawareh \& Jusoh, (2014) have said, most of the students have not utilize smartphone for learning.

In the learning process the teacher uses lecture, discussion, question and answer methods and also with the application of learning models that are assisted with power point presentation media, modeling of computer devices, such as mainboard, memory, hard disk and others. But with the application of learning models and media that have been used by the teacher, it is known that there are obstacles in the learning process of computers and basic networks, namely during the process of learning the focus and activeness of students in the learning process is still lacking. Time limitations in the delivery of material is one of the causes of this, because the learning process only relies on face-to-face learning in the classroom while class hours are limited, so the material cannot be fully conveyed to students. Lack of learning support facilities such as limited use of textbooks due to lack of availability of old textbooks and editions, so students do not have the latest books that can increase student knowledge about the latest information about learning. The textbook used has several drawbacks such as the language does not match the level of thinking of students so it is difficult to be accepted or understood by students and students tend not to like the textbook because it is not accompanied by clear images and illustrations that are not interesting.

The power point media used by the teacher in the learning process as an additional medium still has shortcomings, that is, it only contains learning material without interactive exercises / quizzes and simulations that facilitate interaction between students and the media so that student participation in learning is still lacking. The lack of this media is only focused on the teacher, so that this situation causes some students to be bored with the learning atmosphere, because students only listen to the teacher in class, but it also can reduce student interest in understanding computer materials and basic networks so that later it will affect student learning outcomes and resulting in learning goals not achieved.

The power point media used by the teacher for learning there is no reciprocal interaction between the media and students, because in this media the teacher only summarizes the important points of the material and displays it in front of the class. The picture of a computer device presented on the media is only in the form of photographs, so it does not attract students to really pay attention to the media. In addition, students are less active in carrying out learning so the learning process is monotonous and causes low student interest in understanding the subject matter.

These computer and based network subjects are abstract in theory and practice that makes it difficult for students to understand the material and requires a lot of time to explain the material in detail. This results in students not optimally implementing the existing learning process. Whereas the greater participation of students in learning will be able to improve students' memory and understanding. Besides learning can only be done in the classroom that causes less than the maximum learning if face-to-face process does not occur, things like this can hinder the process of ongoing learning.

Based on interviews, the teachers have a hard time to deliver the course material to students although several students have a good reaction and enthusiastic towards learning process and yet a few of 
the students still less active in the learning process. This problem happens because there is still not enough media or help tool for learners to explain the course material Computer and Based Network which in need to object visualization for example the process of computer assembly. The process of computer assembly must be observed directly because if students learning the course material without the practice and there are no learning tools to help students, the impact of these problems can be either the students feel they do not master the material concept well due to students understanding of the abstract material.

One of the abstract subject for this course is computer assembly and operating system, in which can only be done with practice with the real media as we can say it is the computer but at vocational high school 2 Padang still doesn't have enough computer for students to study, let alone use it to practice computer assembly in which the students need to unload the component in Control Processing Unit (CPU) and to install back the component. This can be risking the healthy computer to cannot be used anymore because the work has been done by the students whom still learning in which have possibility to unsuccessful in assembly the computers. To prevent this thing to happen, one of the solutions at this problem is to developed the learning media which can make students understand the course material media who look like the real computer and students can learn the course like they practice with the real com-puter.

The use of teaching resources in the form of media presented in smartphones is still not optimally being used by the teacher which is only $10 \%$ in this case, whereas Computer and Based Network material requires more detailed and real visualization of objects. Therefore, the use of appropriate teaching resources or media needs more attention. But in reality, in preparation for learning $67 \%$ of teachers did not make their own teaching media but obtained from the internet or only using printed module. From the results of the observation it was also found that students were more interested in learning using various media. Students prefer learning with media that shows how to work, drawings or material in more detail than learning by using only textbooks, modules or textbooks. Students think smartphones can be a very good device and help in learning. Based on the interview, $92 \%$ of students agree to using a smartphone in learning only $8 \%$ of students who answer do not agree when smartphones are used in learning, they think this is less effective.

In conclusion, students need the development of learning media that can increase stu-dents motivation and can improve learning effectiveness. Some teachers explain, using smartphone in learning can be more effective if it was supervised by the teachers, rather than it being under student's productivity. Since the main focus found from student usage was smartphone, this can be used as an advantage to add academic purpose for them using it. This can match what was found on the research paper done by Chen \& Denoyelles, (2013) Establishing a faculty focused group for mobile learning (mlearning) can promote mobile formal academic use. The result of the use of smartphone can somehow be similar to what Gikas \& Grant (2013) have stated, mobile technologies enable learners to find, manipulate, identify and evaluate existing knowledge and successfully integrate and communicate this new knowledge into their work. Mobile learning is accepted to participate in rich learning, advanced technology, contextual and distributed for learning (Crompton, 2014). In addition, it can be accepted that m-learning is about student mobility, and how educators can help students in learning activities without them agreeing on a physical location.

The teachers reveal that learning resources needed to be developed and can be used as a source of independent learning for students is android based m-learning because students can use it wherever and whenever. Therefore, it is necessary to develop a media that can visualize learning material, especially computers assembly which aims to facilitate students in understanding the concepts of learning material that is abstract or cannot be observed directly and can also be used for independent learning.

Research on the benefits of smartphones for learning in the classroom has also been widely carried out, the benefits obtained are providing opportunities for students to learn learning materials and interact with teachers or fellow students outside of class hours via a smartphone device Kukulska-Hulme (2012). The use of smartphones has become common at various levels of education because of their availability and affordability. Due to the rapid development of technology, more and more applications on smartphones are integrated in classroom learning to support the learning process, one of which is mobile learning (m-learning) has been widely used in formal education.

Wu et al (2012) explain that $86 \%$ of research on m-learning gives positive results. Similar results are also found in Chee et al (2017), which explains that "most of the 144 m-learning studies have positive results. Average results are ranked next and negative results are ranked lowest ". Sung et al (2016) explain that "smartphone technology has great potential to facilitate more innovative learning". Students need the development of learning media that can increase student interest in learning and can increase the effectiveness of learning. It is necessary to develop a media that can visualize learning materials, especially computer subjects and basic networks that aim to facilitate students in understanding abstract 
learning material concepts or cannot be directly observed and can also be used for independent learning because students can use them wherever and any time. The research and development that will be carried out at a later stage is only limited to computer assembly subject matter. Given the misconceptions about the material often occur and learning outcomes are still relatively low compared to other material.

This m-learning media has advantages compared to power point media because it is interactive which provides convenience in navigation, can be used to display or load audio, video, images, animations, practice questions that can be used to view feedback automatically immediately, and contains interactive simulations on the computer assembly process where students can do computer assembly directly with the media used without having to use actual computer devices, as if students were in the material taught in real terms. By using m-learning, students' interest in learning can increase because the m-learning media can make the material more interesting by adding video, audio, animation and interactive simulations designed so that students are able to learn independently.

Interactive media is a media that is equipped with a controller that can be operated by the user, so users can choose what they want for the next process (Daryanto, 2016: 69). So that interactive media can overcome the problem of increasing the level of student understanding, because students can choose the material to be studied. Android's ability to display media such as images, photos, videos, sound and text simultaneously can be used to display learning material more concretely so that learning is not boring.

Learning done with interactive learning media can meet the educational process standards that are held interactively, inspiratively, fun, challenging students to actively participate. Preparation of learning planning needs to be done for the implementation of an effective and efficient learning process, so that the achievement of graduates' competency standards that are packaged interactively in the form of text, animation, pictures, learning videos and exercises that can be used by students as material in computer lessons and basic networks.

M-learning media have abstract materials content that is animated, so that students can understand the abstract materials easily with learning media. The use of m-learning based an-droid is expected to make the media of this Research Development is to see the validity of the learning media in the learning of Computer and Based Network, which can support the learning needs of students in improving the learning outcomes.

\section{Methods}

This research is a Research and Development (R \& D). In research aims to produce a product in the form of a valid learning media on android smartphone. This learning media development procedure uses a 4-D (four-D) model. The development process consists of 4 stages of development i.e., define, Design, developing, disseminate (Thiagarajan 1974). Validity test is in the third stage, which is the development stage. In this study is limited to the development stage, is to know the validity of the mobile learning media from material and media experts. After the prototype is complete, the development stage is done. This stage aims to produce valid, practical and effective test products. The validation process is accompanied by discussions or direct interviews with experts about the improvements that must be made by the design of Computer and Based Network learning media which is consulted first with experts, then the design is assessed by competent people (experts) who have understood the principles of media development. The data analysis technique uses descriptive analysis techniques to describe the validity of android based m-learning media.

The validation sheet contains several responses and judgement from experts to the material in the Basic Competence "Applying Computer Assembly" which consists of the compatibility of the material with the m-learning media with the Class X Computer and Based Network syllabus. The instrument is a validation sheet used to obtain data on the level of validity of the learning media developed. The questionnaire was submitted to the material experts and media experts or validators after the learning media design was finished. The validator's assessment of each statement is analyzed using average formula. So that for the range $\geq 0,31$ can be interpreted as a fairly high coefficient, so it can be categorized that the category of validity is in the valid category.

The data analysis technique used for reliability analysis is the Intraclass Correlation Coefficient (ICC). The reliability test between ICC validators is used if there are more than two validators. This study uses three media expert validators and three material expert validators so it uses the correlation coefficient between classes. ICC shows agreement and consistency of each subject assessed by each validator, this model emphasizes the similarity of judgments between validators. ICC values will be high when between validators provide similar ratings. ICC data processing uses the SPSS program using the Two-way Mixed model. This model assumes that the validator involved in this study is a validator that has been determined from the start. This model is then used in data processing in this study, where at the end 
of the processing reliability between the validators is obtained. The results of the analysis of the reliability between the media validators are the criteria presented in the table

Table 1. Classification of Reliability among Validators

\begin{tabular}{ccc}
\hline No & Level of achievement $(\%)$ & Classification \\
\hline 1 & $0,80-1,00$ & Very high reliability \\
2 & $0,60-0,79$ & High reliability \\
3 & $0,40-0,59$ & Medium reliability \\
4 & $0,20-0,39$ & Low reliability \\
\hline
\end{tabular}

Source: Modified from Arikunto (2012: 156)

\section{Result And Discussion}

The m-learning media developed is the media that transforms abstract material into animation in an android smartphone, because there are so many abstract material concepts in Computer and Based Network subjects, so that the m-learning media is expected to help students to understand the abstract material. The validation test phase of the media carried out for the developed learning media can be identified based on the evaluation of the material expert and the media expert. The purpose of the validation activities in this study is to obtain a valid status from the experts. Validation test data is obtained through validation instruments which are filled by several validators who are the experts of learning media and learning material experts. The results of input from experts are made into revised material. Next is the analysis of questionnaire data from the results of the expert validation test.
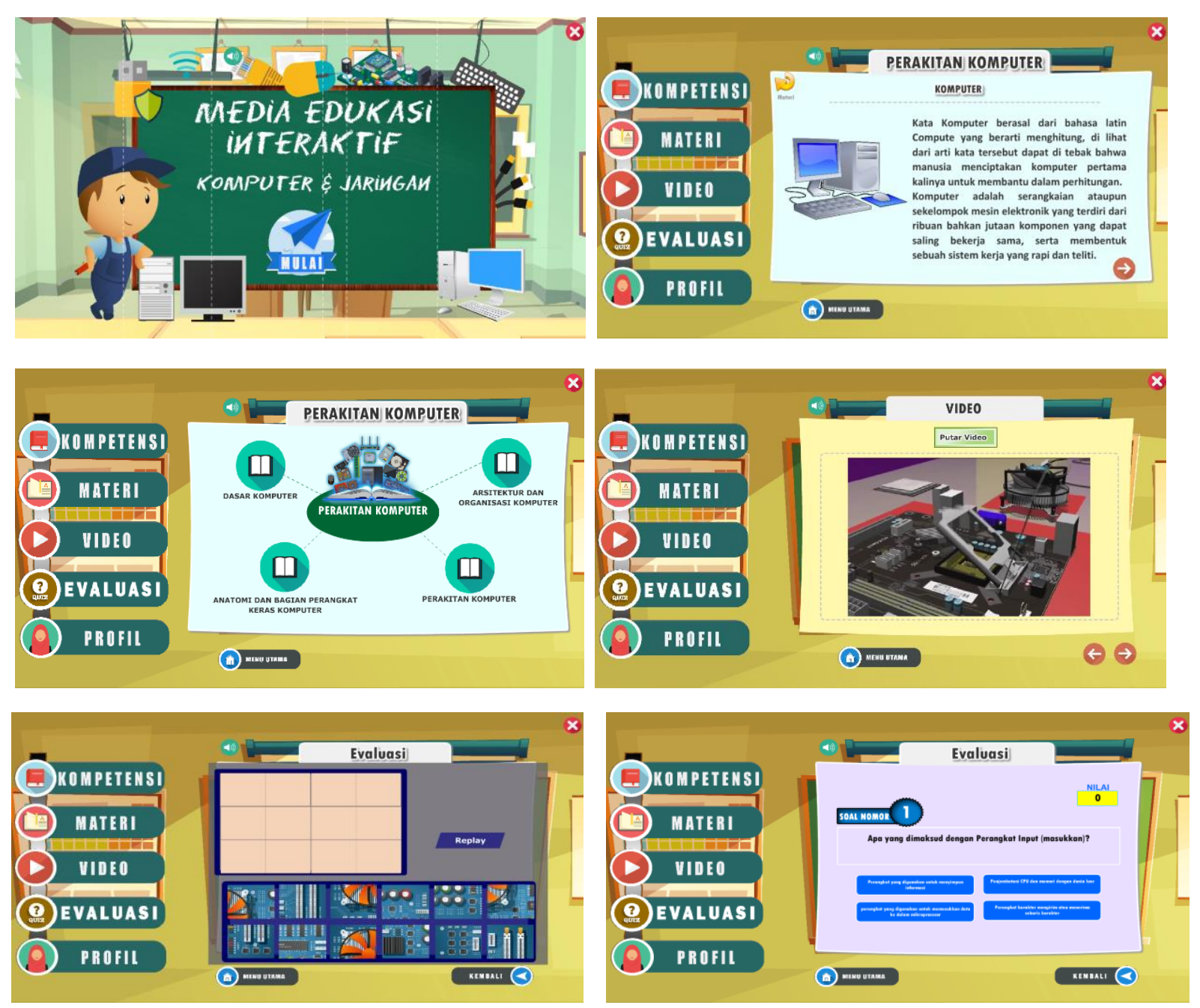

Figure 1. Android based m-learning media 


\section{Material validation}

Material validation was carried out by three experts in the Computer and Based Network subject. The purpose of the material expert validation is to find out the accuracy and suitability of the content aspects of the product that developed whether it is in line with learning needs. Validation assessment data is obtained after the validator provides an assessment of the learning material in the learning media. After that, the validity value data is calculated, the results of the material validity can be seen in the Figure below.

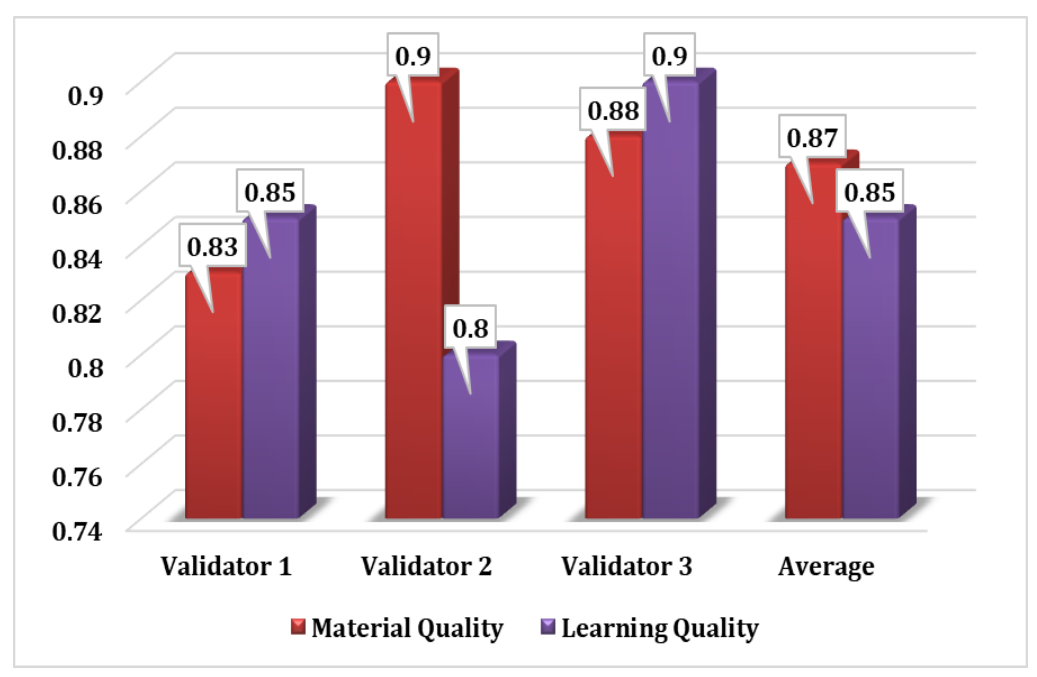

Figure 2. Result of Material Validation

Figure 2 shows that the average validity results from material expert validators in terms of the material quality is 0.87 , the quality of learning is 0.85 and the average of material quality and learning quality is 0.86 which categorized as valid with some revisions to certain parts in media about the material, so it can be concluded that the media android based learning in Computer and Based Network subjects is categorized as valid for use in Class X Vocational High School students.

Table 2. Revised Learning Media Instruction List by Material Experts

\begin{tabular}{lll}
\hline No & Before Revision & After Revision \\
\hline 1 & $\begin{array}{l}\text { Material content must be according to the } \\
\text { syllabus }\end{array}$ & $\begin{array}{l}\text { The material has been adjusted to the syllabus } \\
\text { Enrich the material with the current state of } \\
\text { computer development }\end{array}$ \\
Material content should include one semester & $\begin{array}{l}\text { The material has been enriched with the } \\
\text { current conditions } \\
\text { Material content already includes one } \\
\text { semester }\end{array}$ \\
\hline
\end{tabular}

\section{Media validation}

Media validation is a validation of the product design which is performed by three media expert. Media validation has three aspects of requirements, namely Display Quality, media programming and utilization. Media validation were done twice. After conducting the first validation, the researcher must revise this learning media based on the advice given by the media expert validator, after which the researcher can carry out the second validation to the media expert validator. Then the validator will reassess the learning media and validator assessment. The results of media validation by the validator can be seen in the Figure below. 


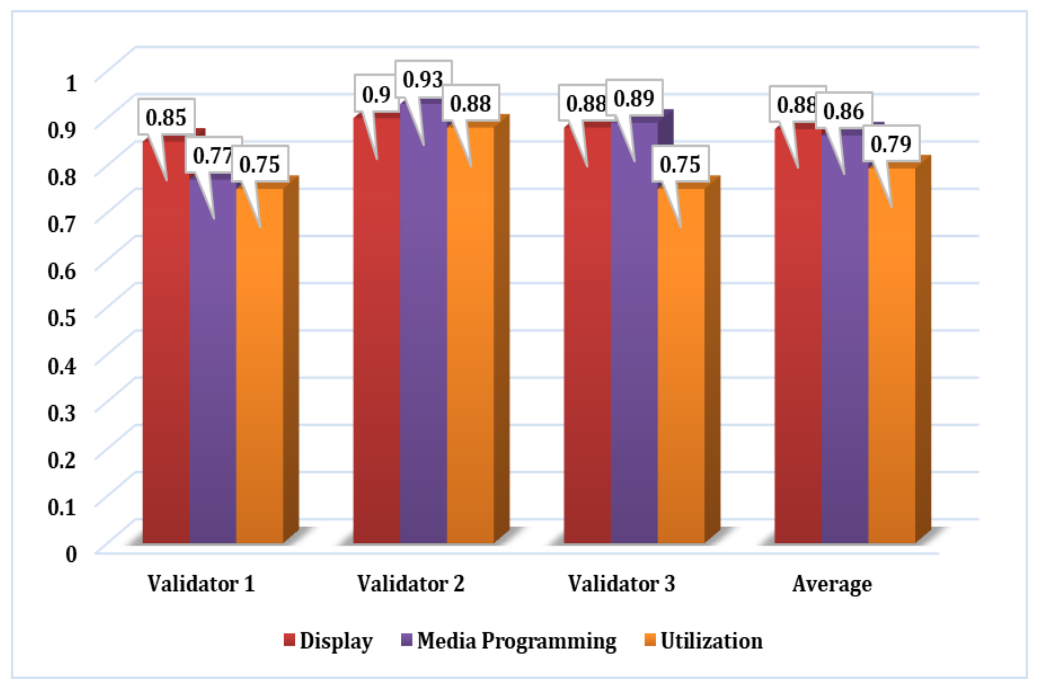

Figure 3. Result of Media Validation

Figure 3 shows that the average validity results from media expert validators in terms of display quality is 0.88 , in terms of media programming is 0.86 , in terms of media programming is 0.79 and the average validity results from media experts in terms of appearance, aspects of media programming and aspects of utilization is 0.84 on the valid category, so it can be concluded that the m-learning media on Computer and Based Network subject are categorized as valid for use in Grade X Vocational High School students. Before performing a second validation, the researcher must make a revision in accordance with the suggestions of improvements that have been given by the expert media validator. The table below are presented the feedback and suggestions from the validators.

Table 3. Revised Learning Media Instruction List by Media Experts

\begin{tabular}{lll}
\hline No & \multicolumn{1}{c}{ Before Revision } & \multicolumn{1}{c}{ After Revision } \\
\hline 1 & $\begin{array}{l}\text { Find a background music in applications that } \\
\text { make the brain work more relaxation for brain } \\
\text { intelligence }\end{array}$ & $\begin{array}{l}\text { Background music has been changed to } \\
\text { music that makes the brain work more } \\
\text { relaxing } \\
\text { Material content must be able to zoom so that } \\
\text { Material content already be zoomed } \\
\text { can be seen comfortably } \\
\text { The "main menu" button does not respond } \\
\text { properly, must be corrected } \\
\text { The button to exit the media should be placed at } \\
\text { the upper right corner }\end{array}$ \\
\hline
\end{tabular}

Based on the data in the table 3, it can be concluded that the m-learning media on the subjects of Computer and Based Network, especially on the basic competence describe the concept of computer assembly is a Valid media. Based on the results of this validity, android learning media expected to be able to the learning outcomes and gaining student motivation in learning as the relevan study said mobile learning improves students' interest and motivation in learning new courses. Besides, mobile devices and wireless networks technologies are improving continuously with time. The evolution of mobile technologies helped e-learning to advanced to mobile learning. In line with the opinion of Sudjana and Rivai (2013) that learning media should meet the requirements of being visible, interesting and accurate, that is, the media should be read easily, be designed attractively, and the media must also be in accordance with characteristics of instructional media. In line with the opinions of the experts, the media is said to be valid if it has fulfilled the aspects of appearance, programming aspects, and aspects of utilization (Mawarni, 2016: 89).

This learning media validation was obtained from the validator's response to the validity of the developed media. The validator consists of six people, namely three people for the media validator and three people from the material validator. Data from the validator was obtained from the validity questionnaire filled out by each validator and discussion by showing this media. In media and material 
validity, the validator provides validation values in the valid category. Based on the evaluation of the validator, both from the material and media aspects, the m-learning media developed is worth testing in the field as a source of learning in Computer and Basic Network subjects. In line with the opinions of experts, the media is said to be valid if it has fulfilled the aspects of appearance, programming aspects, and aspects of utilization (Wahono, 2006: 8).

Based on the value of the validity provided by the validator, the reliability test between the validators is then performed which shows the agreement and the consistency of each subject assessed by each validator. ICC values will be high when between validators provide similar ratings. ICC data processing uses the SPSS program using the Two-way Mixed model. These results indicate that, the average score of reliability assessment among media validators is 0.764 with a high reliability category and reliability among material validators is 0.745 with a high reliability category. From the results of the reliability data analysis above it can be concluded that each reliability value between the media and material expert validators $>0.60$ which means there is high consistency and agreement between the material and media validators.

\section{Conclusion}

The results of the development of this research are products from the android based m-learning media on Computer and Based Network subjects. The process of developing m-learning media refers to the 4-D model, namely Define, Design, Develop, and Disseminate. In this study is limited to the development stage, is to know the validity of the mobile learning media from material and media experts. The subjects of this learning media development experiment were students of Grade X of the vocational high school. After the development process is complete and the m-learning media developed is declared valid, then the m-learning based android is ready to be tested.

Based on the results of data analysis and discussion, it can be concluded that the android based mlearning media on Computer and Based Network subjects for Grade X of the vocational high school is valid with the results of media and material validation in the valid category. So, it can be concluded that the $\mathrm{m}$ learning media is valid for testing on Computer and Based Network learning in vocational high school.

\section{Reference}

Alfawareh, H. M., \& Jusoh, S. (2014). Smartphones usage among university students: Najran University Case. International Journal of Academic Research, 6(2).

Ally, M., \& Tsinakos, A. (Eds.)(2014). Increasing access through mobile learning. Vancouver, BC: Commonwealth of Learning Press.

Arikunto, S. (2012). Prosedur Penelitian Suatu Pendekatan Praktek. Jakarta: PT. Rineka Cipta.

Chee, K. N., Yahaya, N., Ibrahim, N. H., \& Noor Hassan, M. (2017). Review of Mobile Learning Trends 20102015: A Metaanalysis. Educational Technology \& Society, 20(2), 113-126.

Chen, B., \& Denoyelles, A. (2013). Exploring students' mobile learning practices in higher education. Educause Review, 7.

Crompton, H. (2014). A Diachronic overview of technology contributing to mobile learning: A Shift towards student centred pedagogies.

Daryanto. (2016). Inovasi Pembelajaran Efektif. Bandung: Yrma Widya.

Ekanayake, S. Y., \& Wishart, J. (2014). Integrating mobile phones into teaching and learning: A case study of teacher training through professional development workshops. British Journal of Educational Technology,. doi:10.1111/bjet.12131.

Gay, L. R, Mills, G. E., \& Peter, A. (2012). Educational Research:competencies for Analysis and Application. Pearson International Edition. 
Gikas, J., \& Grant, M. M. (2013). Mobile computing devices in higher education: Student perspectives on learning with cellphones, smartphones \& social media. The Internet and Higher Education, 19, 1826.

Hürst, W., Lauer, T., Nold, E. (2007). A study of algorithm animations on mobile devices. In Proc. of the 38 SIGCSE technical symposium on Computer science education (SIGCSE '07), ACM, New York, NY, USA, 39(1), 160-164.

Hung, J. L., \& Zhang, K. (2012). Examining mobile learning trends 2003-2008: A categorical meta-trend analysis using text mining techniques. Journal of Computing in Higher Education, 24, 1-17.

Ihantola, P., Helminen, J., \& Karavirta, V. (2013). How to study programming on mobile touch devices: interactive python code exercises. In Proceedings of the 13th Koli Calling International Conference on Computing Education Research (pp.51-58). ACM.

Jordine, T., Liang, Y., \& Ihler, E. (2015). A mobile device based serious gaming approach for teaching and learning java programming. International Journal of Interactive Mobile Technologies, 9(1), 53.

Kukulska-Hulme, A. (2012). How Should the Higher Education Workforce Adapt to Advancements in Technology for Teaching and Learning? The Internet and Higher Education, 15(4), 247-254.

Mahmoud, Q. H., \& Dyer, A. (2008). Mobile devices in an introductory programming course. ComputerIEEE Computer Society, 41(6), 108.

Mbogo, C., Blake, E., Suleman, H. (2013). A mobile scaffolding application to support novice learners of computer programming. In Proceedings of the Sixth International Conference on Information and Communications Technologies and Development, (2), 84-87.

Moreira, F., Ferreira, M.J., (2016). Teaching and learning modeling and specification based on mobile devices and cloud. In 11th Iberian Conference on Information Systems and Technologies (CISTI), IEEE, 1-6.

Oyelere, S. S., Suhonen, J., \& Sutinen, E. (2016). M-learning: A new paradigm of learning ICT in Nigeria. International Journal of Interactive Mobile Technologies, 10(1), 35-44.

Prenner, G., Rotheneder, A. Schikuta, E. (2014). NetLuke: web-based teaching of algorithm and data structure concepts harnessing mobile environments. In Proceedings of the 16th International Conference on Information Integration and Web-based Applications \& Services, ACM, 7-16.

Schuck, S., Aubusson, P., Kearney, M., \& Burden, K. (2012). Mobilising teacher education: a study of a professional learning community. Teacher Development, 17(1), 1-18.

Sudjana, N \& Rivai, A. (2013). Media Pengajaran. Bukittinggi: Sinar Baru Algesindo.

Sung, Y., Chang, K., \& Liu, T. (2016). The Effects of Integrating Mobile Devices with Teaching and Learning on Students Learning Performance: A Meta-Analysis and Research Synthesis. Computers \& Education, 94, 252-275.

Thiagarajan. (1974). Instructional Development For Training Teachers of Exceptional Children. Minneapolis, Minnesota: Leadership Training Institute/Special Education, University of Minnesota.

Tortorella, R. A.W., \& Graf, S. (2017). Considering learning styles and context awareness for mobile adaptive learning. Journal of Education and Information Technologies, 22(1), 297-315.

Wahono. (2006). Aspek dan Kriteria Penilaian Media Pembelajaran. Jakarta: Prestasi Pustaka Publisher.

Wu, W., Wu, Y., Chen, C., Kao, H., Lin, C., \& Huang, S. (2012). Review of trends from mobile learning studies: A metaanalysis. Computers \& Education, 59, 817-827 